\title{
Impact of Taxation on Price Formation in Agricultural Markets: Example from Antalya Greenhouse Production
}

\author{
C. Sayin ${ }^{1}$, Rahmiye Figen Ceylan ${ }^{1}$, Makbul Nisa Mencet Yelboga ${ }^{1}$, Meral Ozalp$^{2}$, Eda Ilbasmis ${ }^{1} \&$ Oya Sav $^{1}$ \\ ${ }^{1}$ Department of Agricultural Economics, Faculty of Agriculture, Akdeniz University, Antalya, Turkey \\ ${ }^{2}$ Department of Accounting and Tax Applications, Kumluca Vocational College, Akdeniz University, Antalya, \\ Turkey
}

Correspondence: Rahmiye Figen Ceylan, Department of Agricultural Economics, Faculty of Agriculture, Akdeniz University, Faculty of Agriculture $5^{\text {th }}$ Block $3^{\text {rd }}$ No. 305 Campus Konyaalt1, Antalya, Turkey. Tel: 90-242-227-4400/2534. E-mail: ceylan.figen@gmail.com

Received: March 6, $2017 \quad$ Accepted: April 17, $2017 \quad$ Online Published: May 15, 2017

doi:10.5539/jas.v9n6p120 URL: https://doi.org/10.5539/jas.v9n6p120

The research is financed by Research and Development Program of General Directorate of Agricultural Research and Policies - TAGEM.

\begin{abstract}
Taxation of economic activities is inevitable for formation and maintenance of national budgets. However, the level and payment structure of the taxes and reactions of taxpayers should be considered carefully in the scope of proper management of the taxation system. Agriculture, being the first taxed sector, provides limited insight for assessment of taxation systems. With the field survey conducted with 281 glass and plastic house producers from Antalya, Turkey, it was aimed to understand the impacts of taxes payed on the profitability of farm enterprises as well as main socio-demographic factors. It was found that the enterprises, $76 \%$ of which are taxed on real income, achieved to produce 7.190,73 TL $(2.463,25 \mathrm{USD})$ profit per $1.000 \mathrm{~m}^{2}$. Following calculation of the profit level, it was intended to analyse the factors effecting profit inefficiencies of the farm enterprises.

Accordingly, stochastic profit frontier was estimated with the data retrieved and it was concluded that both the direct income tax and indirect value-added tax could be used as policy tools to increase profitability and attain sustainability of greenhouse production sector, which is a dominant sector in the Mediterranean region of Turkey. That's why both tax indicators seemed to be in negative relation with the profit level and there is a possibility to reduce the inefficiency specifically with a VAT revision for the inputs.
\end{abstract}

Keywords: profit efficiency, greenhouse, production, cost, stochastic profit frontier

\section{Introduction}

Taxes which constitute one of the most important and sustainable income sources bear economic and social functions. Accordingly, taxes affect production, consumption, savings, investment and employment and bear a regulatory role in development of national economy with its increasing load over the national budget.

One of the most important characteristics of taxes is that they are directly transferred from nationals of a country to the national economy, without awaiting a direct return on it. The conditions, measure, reason and timing of the tax transfers are determined by the authority that accepts the payments with regards to the financial law (Neumark, 1948; Tufan, 1988). The social function of taxes appears however, during the collection and use of taxes for public interest. The income level correcting effect of taxes maintains its importance within the society. As an instance, tools to assure exemptions and deductions on tax base are used to arrange level of taxes respecting the economic strength of the target audience (Tufan, 1988).

The oldest tax variety is agricultural taxes as the initial economic activities are agricultural in the world. Taxation of agricultural income and earnings vary across countries with respect to the contemporary economic and social structure. Agriculture constitutes an important tax potential in Turkey due to its weight in the gross national income. Agriculture is more dependent on natural conditions than other sectors, there are technical problems in calculation of agricultural income and income fluctuations from year to year. Due to these features and due to the 
strategic position of agriculture, taxation of agriculture is a strategic topic to be studied carefully for Turkey. Besides, agricultural taxes have supplementary roles in addition to their function to meet public needs. Agricultural taxes are accepted as important policy tools in direction of agricultural production and in affecting income distribution with respect to objectives set forward (Hayran, 2013).

This study was planned due to the need to determine the problems regarding taxation of agriculture and to search for the improvement possibilities. Estimation of the impact of taxation is also important to determine the strength of taxation as a policy tool. Field studies were conducted in one of the important agricultural production and export centres of Turkey. The greenhouse producers, including glasshouses, in the centre and in two main agricultural towns of Antalya were surveyed and stochastic frontier estimation was made with the data retrieved from 281 producers. The main objective was to determine the effects of taxes collected on producer profit levels.

\section{Analysis and Evaluation of Agricultural Taxes}

There are various studies focused on the share of taxes on agricultural income and effects of taxes on profitability of the sector. One of the earliest studies is, 'Taxing Agricultural Land in Developing Countries' by Bird (1974). In the first section of the book the relationship between agriculture and taxes are analysed, which is followed by evaluation of varieties and advantages and disadvantages of taxes. Bird had suggested that intensive taxation of agriculture is not correct and the taxes should be land based rather than quantity based, after having analysed the tax regimes and implementations in Northern America, Japan, Mexico and India. In other words, Bird considered taxation of the main input, land, rather than taxing production which is translated into de-coupled taxation of today.

Ahmad and Stern (1991) had analysed tax reform approaches in the scope of economic principles and rules in their study. They suggested consideration of households and sector stakeholders as producers and state organisation in development of tax policy simultaneously. In another study, in addition to the indirect taxes imposed in agriculture, the effects of grain quotas and other taxes were measured for Ethiopia (Nelson, 1997).

The exports and R\&D investments were determined for Africa by using a growth regression. With this, the policy tools used by local governments were analysed with game theory in Africa. It was suggested that policy makers could cope with low growth barriers with implementing low taxes/high investment strategy (McMillan \& Masters, 1999).

Khan (2001) had analysed agricultural taxation regimes in developing countries with respect to structures and effects of taxes. It was found out that the income from direct taxes did not increase after reduction of agricultural export taxes in most of the Latin American and Asian countries. Accordingly, it was claimed that the main reason behind the problems was measurement of agricultural taxes. Even there observed rise on income levels in some countries due to differences in measurement errors, the taxes were restricted due to political and administrative reasons.

Bezlepkina (2002) had compared the relationship between tax implementations and production efficiency in 76 different regions of Russia. While the 1992 agricultural reforms had foreseen increase in efficiency and profitability of the production in Russian agriculture, it was found that the budget transfers to farmers resulted in production inefficiency and rising taxes on farm level.

Rajaraman (2004) had suggested that agriculture was one of the hardest taxation fields for developing countries. Shaping taxation policies with regards to efficiency, effectiveness and equity principles was suggested. It was also proposed that the product specific taxation in agriculture could only be implemented by central organisations departing from the example of India.

Godinho and Coelho (2005) considered transformation in agricultural enterprises in Portugal by accession to the European Union in 1986. The agricultural taxes implemented were classified due to kinds of enterprises and the impact of tax reform on producers was analysed. The study focused on problems of tax regimes and suggested that the main problem was measurement of incomes.

Lin and Liu (2007) had focused over transformation of agricultural taxes in China within the reform period. They indicated that there was asymmetric information between local governments and central policy making institutions. Due to the requirements to follow central policies, local governments had imposed illegal taxes. Another significant finding of the study for China was that the low-cost tax tools were removed as the grain market was liberalised.

Hill and Blandford (2007) had claimed that tax exemptions supported income levels, leaded rise in agricultural welfare and taxes could be environmental policy tools. They have concluded that different tax implementations had international trade destruction effects for agricultural producers with respect to comparative advantages. 
Huand et al. (2008) had analysed agricultural trade reform in China from 1981. They have concluded that membership of China to the World Trade Organisation resulted in rapid decline in agricultural tariffs and export protectionism had negative outcomes for trade balance. In addition, they emphasized that sharp decline in agricultural taxes and removal of production quotas leaded declination both in exports and imports.

Casamatta et al. (2001) had suggested that effective resource allocation in agriculture can be achieved by imposing taxes on agricultural products and inputs like land and labour. They emphasized that the role of subsidies was to reallocate income from consumers to producers.

In another study, the agricultural taxation process in China between 1950 and 2003 was analysed (Zhong et al., 2011). The effects of amount and ratio based taxes were compared and it was found out that amount taxes affected consumption, while ratio based taxes affected both consumption, investment input and final product amount. It was concluded that agricultural taxes had negative impact on agricultural production.

It was indicated that agriculture was exempted from taxation in Morocco where $44 \%$ of employment is agricultural until 2013 (Karim \& Ibrahimi, 2013). However, this advantage resulted in inefficiency in investment and resource allocation. Additionally, it was concluded that agricultural taxation did not affect competitiveness with dynamic general equilibrium methods. Tantari et al. (2014) analysed agricultural taxation in Italy. The tax load on agricultural enterprises was analysed and the findings indicated that the effect of income level on tax load is negligible.

Accordingly, it was intended to analyse effects of changing tax implementations on agricultural income and field studies were conducted in Antalya, Turkey in 2016.

\section{Data and Methodology}

\subsection{Data}

The study was conducted in Centre, Serik and Kumluca towns of Antalya with plastic or glasshouse producers. The sample was calculated with Neyman method (Yamane, 2001). The sample calculated with reference to number of greenhouse farms in the target region irrespective of the scale of production and it referred to 275 enterprises within $95 \%$ confidence interval. The final sample is distributed respecting the farmer population ratio of the surveyed farms in three towns. A face to face survey was conducted with 281 producers respecting accessibility and the distribution of the sample was demonstrated in Table 1.

Table 1. Random sample and total number of questionnaires

\begin{tabular}{llll}
\hline Town & Population & Sample & No. of surveys \\
\hline Antalya Centre & 1.500 & 35 & 43 \\
Kumluca & 10.000 & 185 & 183 \\
Serik & 3.000 & 55 & 55 \\
TOTAL & 14.500 & 275 & 281 \\
\hline
\end{tabular}

\subsection{Methodology}

The socio-economic findings and main agricultural indicators residing on the retrieved data were provided initially. Following this portrait, the unit gross profit of enterprises was calculated and this profit was analysed in the scope of production activities and costs incurred (Sidhu \& Baanante, 1981; Chambers et al., 1998).

Variable (production inputs) and fixed (ownership of land and machinery, depreciation accumulated, interest expenses and administrative expenses) costs were considered carefully taking the unit production area $\left(1.000 \mathrm{~m}^{2}\right)$ as reference in calculation of the income and profit levels of concerned enterprises. The unit profit was calculated for unit production area and the variation between enterprises was assumed to be based on quality.

The relationship of net farm income and gross profit with taxes collected was analysed with coefficient estimates of direct and indirect tax indices that were included to Cobb-Douglas profit function (Chambers et al., 1998). Accordingly, the main equation utilised is as following.

$$
\pi_{i}=f\left(P_{i j}, Z_{i k}, D_{i j}\right) \exp \left(e_{i}\right)
$$

Where,

$\pi_{i}=$ unit profit of the $i^{\text {th }}$ enterprise calculated after deduction of variable costs from total farm income (per 1000 $\left.\mathrm{m}^{2}\right)$ 
$P_{i j}=$ price of the $j^{\text {th }}$ input used by the $i^{\text {th }}$ enterprise;

$Z_{i k}=$ the level of $k^{\text {th }}$ fixed production factor owned by the $i^{\text {th }}$ enterprise;

$D_{i j}=$ level of $j^{\text {th }}$ direct or indirect tax born by the $i^{\text {th }}$ enterprise;

$e_{i}=$ error term.

The input prices used in estimation of the inefficiency index were production land $\left(1000 \mathrm{~m}^{2}\right)$, fertilizer cost $\left(\mathrm{TL} / 1000 \mathrm{~m}^{2}\right)$, pesticide cost $\left(\mathrm{TL} / 1000 \mathrm{~m}^{2}\right)$, seedling cost $\left(\mathrm{TL} / 1000 \mathrm{~m}^{2}\right)$ and depreciation of greenhouse house machinery (TL).

In the second step of the research, the effects of tax load and relevant socio-demographic characteristics of the farmer and farmer family on the profit inefficiency were analysed. The inefficiency indices of the target enterprises ranging between 0 and 1 were retrieved from the error terms of logarithmic profit function estimates. The variation of the profit function's error terms is composed from the sum of profit inefficiency, $\sigma^{2}=\sigma_{u}{ }^{2}+\sigma_{v}{ }^{2}$. (Batesse \& Cora, 1977; Batesse \& Coelli, 1993; Kolawole, 2006). Besides, the inefficiency score can be retrieved from the anti-log of the variation.

Following quantitative evaluation of the inefficiency score, the impact of social and demographic factors on the inefficiency was analysed.

$$
K E I_{i}=f\left(A_{i}, T_{i}, H_{i}, V g_{i}, V s_{i}, \dot{I}_{i}, S_{i}\right)
$$

Where,

$K E I_{i}=$ profit inefficiency index of the $i^{\text {th }}$ enterprise;

$A_{i}=$ age of the farmer in the $i^{\text {th }}$ enterprise;

$T_{i}=$ education level of the farmer in the $i^{\text {th }}$ enterprise;

$H_{i}=$ number of households in the $i^{\text {th }}$ enterprise;

$V g_{i}=$ income based tax payment situation of the $i^{\text {th }}$ enterprise (Yes: 1, No: 0 );

$V s_{i}=$ Stoppage based tax payment situation of the $i^{\text {th }}$ enterprise (Yes: 1, No: 0 );

$\dot{I}_{i}=$ Dummy variables referring to the geographical location of the $i^{\text {th }}$ enterprise (Central town - Kumluca-Serik);

$S_{i}=$ Dummy variables referring ownership of greenhouse or glasshouse of the $i^{\text {th }}$ enterprise.

The analysis was conducted with utilisation of NLOGIT 5 statistical package. MS Excel was used in demonstration of the descriptive findings.

\section{Results}

\subsection{Economic Findings and Unit Profit}

\subsubsection{Tax Paying Situation of Producers}

Firstly, the tax paying situation of 281 enterprises were evaluated. The greenhouse enterprises paying taxes based on real income were separated from those that make stoppage implementations. Real income based tax payers were also classified due to financial books they keep and they were evaluated as either making tax payment due to agricultural enterprise accounts or balance sheet. Accordingly, almost $76 \%$ of the surveyed farmers were paying taxes due to agricultural enterprise accounts while $22 \%$ were stoppage based payers. In addition, it was found out that 135 producers were keeping their accounts and making notifications to tax authorities.

Producers were asked to indicate the income and land taxes they pay. The average income tax had appeared as 1.132 TL (387,78 USD). However, land tax used to appear as low as 227 TL (77,76 USD) due to the location of the farmland. Most of the farms are residing on agricultural lands rather than municipal inhabitancy lands.

\subsubsection{Sales Location}

The sales outlet of the products was asked to the producers. The main outlets appeared as district bazaars, wholesale markets, sales to intermediaries and direct open market sales. Accordingly, 213 or the producers surveyed, which means $76 \%$ of the participants, indicated that they make wholesale market sales. 12 of the producers $(5 \%)$ make district bazaar sales and the remaining use a composition of the different channels. This means that most of the producers follow pre-agreements for production and delivery to the wholesale markets.

\subsubsection{Production and Sales}

The main products of the surveyed greenhouse farmers appeared to be tomato, green pepper, aubergine, cucumber and pumpkin. Therefore, most of the producers declared that they produce vegetables. This means that 
the production tradition of the region towards 'vegetable production and exports' is being followed. As the product varieties and land size differ between farms, per unit income and costs were taken as reference respecting $1.000 \mathrm{~m}^{2}$.

Average production amount for 281 producers was 35 tons with reference to one production period. The average income was found out as 54.472,95 TL (18.660, 23 USD) and the distribution was demonstrated in Figure 1.

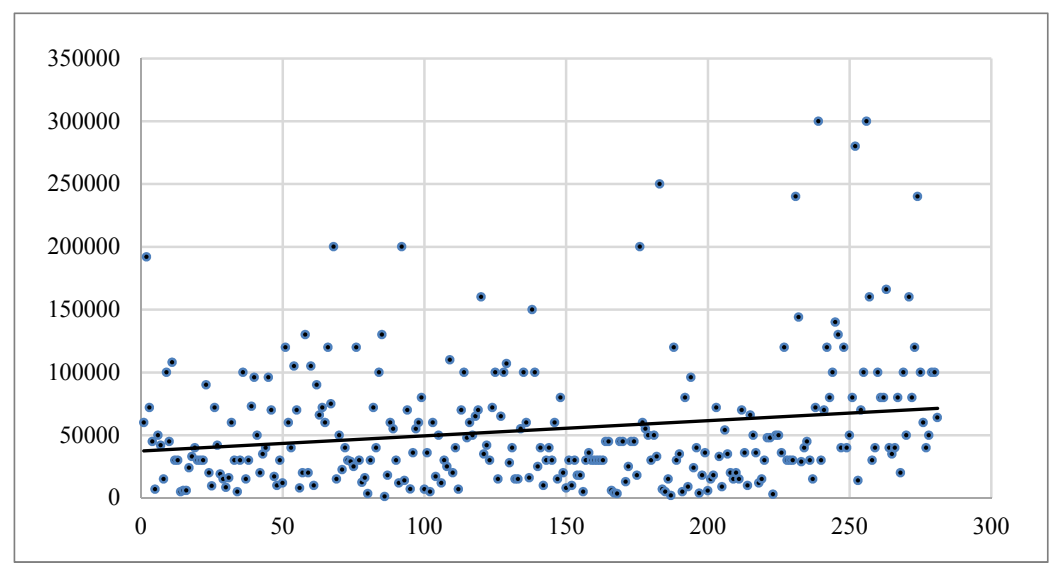

Figure 1. Total income of greenhouses

However, evaluating the distribution of income with respect to the location of greenhouse farms provided us information regarding the production structure. Accordingly, the average income of producers in Kumluca, where plastic houses are more common was found out lower than Antalya Central town as shown in Table 2.

Table 2. Total income and variable costs of enterprises (TL - USD)

\begin{tabular}{|c|c|c|c|c|}
\hline & Total Income (TL) & Total Income (USD) & Total Variable Cost (TL) & Total Variable Cost (USD) \\
\hline Antalya Centre & $57.899,33$ & $19.833,97$ & $26.879,72$ & $9.207,91$ \\
\hline Kumluca & $47.892,11$ & $16.405,90$ & $26.340,68$ & $9.023,25$ \\
\hline Serik & $49.081,55$ & $16.813,36$ & $26.267,93$ & $8.998,33$ \\
\hline TOTAL & $54.472,95$ & $18.660,23$ & $26.730,02$ & $9.156,63$ \\
\hline
\end{tabular}

\section{(1) Production Costs}

Costs incurred during the production process was considered both with the use of the input and the labour requirement of the process. The average of total variable costs per farm was found almost 9.000 USD when the average income was 18.000 USD. While there was no significant difference in per unit costs between the target towns, they were found higher in the central town where most production was with glasshouses and with commercial objectives. This meant that production units had been operating with $50 \%$ profit level. This rate could be addressed to the surveyed farms only and it can be generalised neither to all greenhouse production, nor to all producers in Antalya.

Demonstration of specific expenditures prior to the analysis was considered as essential. The alternative cost calculation methods were used in calculation of labour costs for all cost units and family labour was included to the calculation considering the average labour costs. The details of cost structure are as follows.

\section{(2) Seedling Costs}

It was understood that seedling is one of the major costs and the average rate was around 2.200 USD which rose to 2.790 USD with inclusion of labour costs incurred in the production period. The highest seedling cost was encountered in the central town while it was lowest in Kumluca with reference to the production term. The findings were demonstrated in Table 3. 
Table 3. Seedling costs - average (TL - USD)

\begin{tabular}{lllll}
\hline & Seedling Cost (TL) & USD & Seedling + Labour Cost (TL) & USD \\
\hline Antalya Centre & $7.100,18$ & $2.432,23$ & $8.700,08$ & $2.980,30$ \\
Kumluca & $5.537,93$ & $1.897,07$ & $7.224,49$ & $2.474,82$ \\
Serik & $6.250,98$ & $2.141,33$ & $7.903,31$ & $2.707,35$ \\
TOTAL & $6.471,09$ & $2.216,73$ & $8.147,30$ & $2.790,94$ \\
\hline
\end{tabular}

\section{(3) Fertilizer Costs}

The target greenhouses focused on production of different vegetable varieties used to incur 905 USD of average fertilizer costs. 678 USD of labour costs incurred for fertilization activities on average. The highest fertilizer costs was encountered in Serik, while the highest labour cost attached was found in the central town as demonstrated in Table 4.

Table 4. Fertilizer cost - average (TL - USD)

\begin{tabular}{lllll}
\hline & Fertilizer Cost (TL) & USD & Fertilizer + Labour Cost (TL) & USD \\
\hline Antalya Centre & $2.740,25$ & 938,70 & $5.033,75$ & $1.724,36$ \\
Kumluca & $2.637,04$ & 903,34 & $4.458,83$ & $1.527,42$ \\
Serik & $2.833,58$ & 970,67 & $4.672,47$ & $1.600,60$ \\
TOTAL & $2.644,37$ & 905,85 & $4.624,37$ & $1.584,12$ \\
\hline
\end{tabular}

\section{(4) Pesticide Costs}

The pesticide costs and attached labour costs were also calculated. It is important to note that the pesticide costs found are lower than expected due to lack of knowledge of producers regarding the exact amount and brand name of the chemicals they used. Yet, it was again significant that average cost of chemicals was higher in glasshouse tomato production and respectively in Kumluca town than the other target districts. It was demonstrated in Table 5 that average pesticide costs was around 140 USD and around 450 USD was needed to be included in the costs.

Table 5. Pesticide cost - average (TL - USD)

\begin{tabular}{lllll}
\hline & Pesticide Cost (TL) & USD & Pesticide + Labour Cost (TL) & USD \\
\hline Antalya Centre & 239,32 & 81,98 & $1.547,32$ & 530,05 \\
Kumluca & 509,52 & 174,54 & $1.869,70$ & 640,48 \\
Serik & 399,22 & 136,76 & $1.593,03$ & 545,71 \\
TOTAL & 413,40 & 141,61 & $1.706,54$ & 584,59 \\
\hline
\end{tabular}

\section{(5) Oil-Energy Costs}

The quality and value of the oil used also differed due to the greenhouse type. While electricity, coal and wood costs appeared to be negligible with 100 USD, the most significant energy cost account had appeared as fuel-oil cost. The highest fuel-oil cost was detected in the farms in Kumluca. Reasoning behind was considered as the prevalence of glasshouses and climatic effects for the winter period being more effective than the other towns. However, the total value of oil-energy costs with the labour incorporated was 964,02 USD, the figure being highest in Kumluca town with 1.156,93 USD on average.

\section{(6) Irrigation Costs}

Besides being different due to the scale of the enterprise, the average cost of irrigation for the production period had appeared as 110 USD. The labour cost included was 50 USD on average.

(7) Maintenance and Renovation Costs

In addition to main variable costs, maintenance and renovation costs of green and glasshouses do also constitute a significant cost account. It was possible to note that the establishments in the target region need maintenance and renovation once in 3 years. The average of the costs was indicated as $6.060 \mathrm{TL}$ (2.075 USD). 
(8) Greenhouse Investment Costs

Investment costs do constitute an important cost account especially when considered together with depreciation. Average investment costs are almost the same in target towns. However, in the central town, where modern glasshouses are more widespread the investment-installation costs were appeared higher.

In addition to these costs, the Value Added Tax born by the enterprises with regards to their purchases should be evaluated. Accordingly, the indirect cost load because of the variable inputs as fertilizers, seeds, pesticides and irrigation had appeared as 366,54 USD on average for $1.000 \mathrm{~m}^{2}$.

\subsection{Stochastic Profit Frontier}

The gross profit calculated after deduction of all variable and constant costs from the declared total income is one of the significant findings of the face to face survey with 281 greenhouse producers. By analysis of the gross profit with reference to variable costs for the relevant sample, stochastic profit frontier was estimated. The level of gross profit $(\mathrm{Y})$ with respect to town centres $(\mathrm{X})$ is provided in Figure 2.

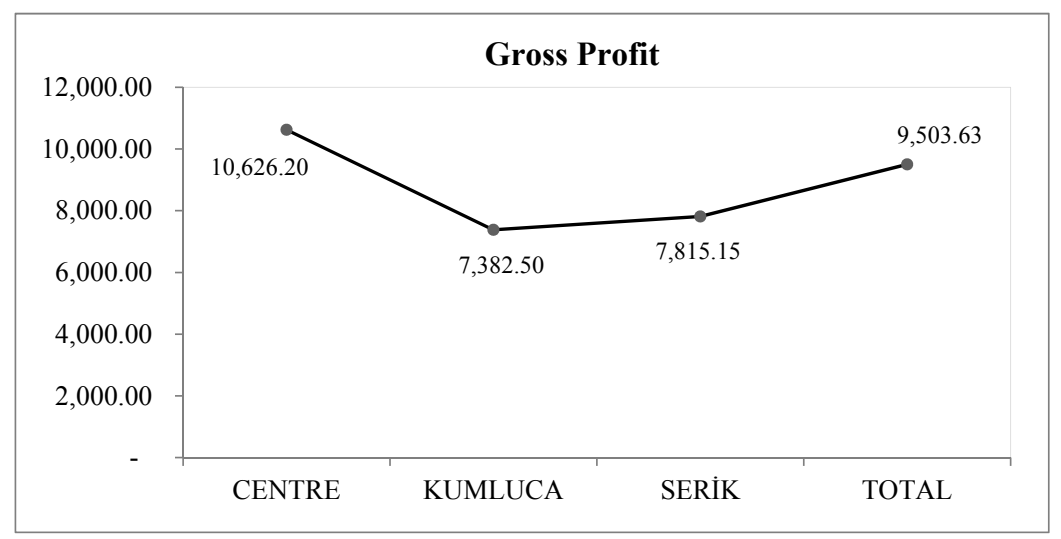

Figure 2. Gross profit of agricultural enterprises (USD)

In order to evaluate gross profit with variable cost accounts and in order measure variation accurately, the gross profit needed to be used with reference unit production area. Therefore, the average gross profit for 281 enterprises per $1.000 \mathrm{~m}^{2}$ was found out as 7.190,73 TL (2.463,25 USD).

The profit frontier analysis, where gross profit was the dependent variable, logarithmic transformation was made with reference to $\log$-probability value $(\mathrm{LR}=55)$. The estimation enabled us to retrieve the inefficiency scores.

The impact of A: greenhouse land $\left(1.000 \mathrm{~m}^{2}\right)$, G: fertiliser cost per enterprise (TL/1.000 $\left.\mathrm{m}^{2}\right), \mathrm{F}$ : seedling cost per enterprise $\left(\mathrm{TL} / 1.000 \mathrm{~m}^{2}\right), \mathrm{K}$ : pesticide cost per enterprise $\left(\mathrm{TL} / 1.000 \mathrm{~m}^{2}\right)$ ve D: depreciation per enterprise (TL) was measured on gross profit per $1.000 \mathrm{~m}^{2}(\ln \mathrm{Pi})$. The cost of labour including family labour was not included in the analysis as it did not allow variation. The final equation implemented is as following.

$$
\ln \pi_{i}=\beta_{1} \cdot A_{i}+\beta_{2} \cdot G_{i}+\beta_{3} \cdot F_{i}+\beta_{4} \cdot K_{i}+\beta_{5} \cdot D_{i}+\left(u_{i}+v_{i}\right)
$$

Table 6. Stochastic profit frontier estimates

\begin{tabular}{llll}
\hline & Coefficient & Standard Error & $|\mathrm{z}|>\mathrm{Z}^{*}$ \\
\hline Constant & 5 & 0,659 & 30,35 \\
$\mathrm{~A}_{\mathrm{i}}$ & $2,46^{* * *}$ & 0,103 & 21,80 \\
$\mathrm{G}_{\mathrm{i}}$ & $0,005^{* * *}$ & 0,0007 & 6,63 \\
$\mathrm{~F}_{\mathrm{i}}$ & $0,0006^{* * *}$ & 0,002 & 4,14 \\
$\mathrm{~K}_{\mathrm{i}}$ & $2,07 * * *$ & 0,004 & 8,91 \\
$\mathrm{D}_{\mathrm{i}}$ & $0,01 * * *$ & 0,0003 & 4,28 \\
\hline Note. & **\% 1- significant. & &
\end{tabular}


The inefficiency scores retrieved from the profit frontier was separated to be used in the second phase of the analysis. With utilisation of this index series, it was searched whether the inefficiencies observed were coincidental or they depended on production factors. Accordingly, it was analysed whether producers could increase their profit efficiency or not in accordance with measurement of the impact of taxes on the inefficiency (Aktaş et al., 2011).

The average inefficiency score was $57 \%$ and it ranged between $7 \%$ and $87 \%$. This percentage shows how much could the efficiency be increased in addition to the existing efficiency level. The reasoning behind the efficiency and under what conditions it could be purified was estimated.

Due to the findings provided in Table 7, the potential factors that could lead reduction in the $57 \%$ of average inefficiency were household size, stoppage form payment of income tax rather than real income based taxation. Accordingly, taxation due to declaration of the producer seemed to be a reason to increase profits in greenhouse production.

Table 7. Inefficiency model estimates

\begin{tabular}{llll}
\hline & Coefficient & $|\mathrm{t}|$ & $\mathrm{P}(\mathrm{t})$ \\
\hline Constant & 4.04 & 10,78 & $0,00^{* * *}$ \\
$\mathrm{~V}_{-} \mathrm{A}_{\mathrm{i}}$ & 0,04 & 1,13 & 0,25 \\
$\mathrm{H}_{\mathrm{i}}$ & $-0,12$ & 3,19 & $0,00^{* * *}$ \\
$\mathrm{~S}_{\mathrm{i}}$ & $-0,14$ & 1,20 & 0,23 \\
$\mathrm{C}_{\mathrm{i}}$ & 0,02 & 2,11 & $0,03^{* *}$ \\
$\mathrm{VAT}_{\mathrm{i}}$ & 0,38 & 9,97 & $0,00^{* * *}$ \\
$\mathrm{Y}_{\mathrm{i}}$ & 0,001 & 0,01 & 0,9 \\
$\mathrm{~V}_{-} \mathrm{G}_{\mathrm{i}}$ & 0,38 & 1,5 & 0,13 \\
$\mathrm{E}_{\mathrm{i}}$ & 0,07 & 1,51 & 0,13 \\
\hline$* * \%$ 1- significant; **\% 5- significant. & &
\end{tabular}

The rise in the income tax or VAT load seemed to be the factors increasing inefficiency. This situation is compatible with the economic expectations of the target region, even when the expectations on significance of the parameters were set aside. In other words, the rise in direct and indirect taxes lead a rise in the inefficiency of enterprises. It was understood that the load of both the income tax and VAT departs producers from the profit frontier.

However, while the ageing of the producer is a factor that slightly reducing the inefficiency, potential of using household labour or the number of households are significant factors in reduction of the profit inefficiency level. While the land tax is an inefficiency reducing factor specifically for producers that operate in their own lands, the impact is less significant.

As more investment and renovation costs are required for glasshouses, this cost seemed to reduce profit efficiency at least slightly. In addition, the finding of rise in the producers' education level that affect the profit inversely considered to be compatible with the previous agricultural research as education level is an incentive to seek alternative jobs out of agriculture.

\section{Discussion}

The profit efficiency of randomly selected 281 greenhouse producers settled in Serik, Kumluca and central towns of Antalya, Turkey was investigated with utilisation of stochastic profit frontier in the scope of our study. The unit profit of these 281 enterprises was calculated respecting green and glasshouses and the variable costs affecting the profit level was estimated using profit frontier. The inefficiency scores retrieved from this analysis were used to measure the effects of direct and indirect taxes and relevant social and demographic factors on the profit inefficiency.

Average age of the interviewed producers was above 40 as expected and average education level was elementary-secondary. The average household size of the greenhouse producer family was 4 and members of households were mostly involved in production activities. Besides, the greenhouses mostly belonged to the producer families, as expected for the Mediterranean region, rather than being rented. 
Whether the interviewed enterprises were bound to income tax or not is important for the current research. While most of the producers were taxed based on real income, the share of taxation with reference to 'agricultural enterprise account' was $76 \% .22 \%$ of the enterprises were taxed with reference to stoppage method.

The production costs were analysed one by one. The results indicated that greenhouses bare costs compatible with the expected cost structure. However, the pesticide costs were considered to be declared lower than expectations. As the declarations were similar within the sample and as there was no variation problem, the pesticide costs were kept respecting responses received. The declared costs leaded us to understand that production costs were lower for greenhouse farms in Kumluca, where small scale production is more common. This situation is related with the fact that conventional production in modern glasshouses leaded higher costs for retrieving higher incomes.

The profit assessment follows evaluation of the costs. The profit level for 281 enterprises was found out as 27.000 TL (9.249 USD) while profit per $1.000 \mathrm{~m}^{2}$ was 7.190,73 TL (2.463,25 USD). Following calculation of the profit levels and composition of the profit frontier through assessment of the distance to the frontier, the profit inefficiency of the enterprises was analysed. The analysis showed that rising tax load leads to rising profit inefficiency. In addition, the share of glasshouses within the enterprise and rising producer education level appeared as factors increasing the inefficiency level. In other words, traditional greenhouse producers seemed to be more confident regarding their profit rates looking at the limited impact of education level.

The age of the producer was found out to have very limited effect on efficiency of production performances. This could be related with the 40 years old average age of the producers which signs the level of expertise and openness to new information simultaneously.

Even when less significant quantitative effect of income tax was considered, it was understood that both the income tax and VAT reduces profit efficiency.

Following the analytical sections of the study, the producers were asked to indicate their reactions to tax implementations and procedures they faced with. Due to the answers retrieved for these questions, even when the producers consider the high load of taxes they confirm sustainability of it. In other words, an important number of producers indicated that they do not deny the tax payment responsibilities and they are confident with the services they receive during the tax payment procedures.

Following all these findings, it is possible to note that specifically a reduction on VAT for the agricultural and conventional inputs of greenhouse production sector seemed to benefit profit levels of greenhouse producers. VAT revision seemed to affect long-term profitability and sustainability of greenhouse production. The lower profit inefficiency levels for the producers that pay income tax on stoppage based calculation and reporting methods is another significant finding that could be translated into policy and implementations.

In addition, the openness of producers to new learning with respect to their age and level of expertise is another important finding. Development of extension services could be considered as essential to improve the productivity levels especially for greenhouses in the target region.

\section{Acknowledgements}

We would like to thank Research and Development Program of General Directorate of Agricultural Research and Policies - TAGEM. The research was prepared in the scope of the project entitled "TAGEM-14/ARGE/63 taxation in agricultural markets and effects of taxation on price formation: example from Antalya greenhouse production".

\section{References}

Ahmad, E., \& Stern, N. (1991). The theory and practice of tax reform in developing countries. Cambridge, UK: Cambridge University Press.

Aktaş, A. R., Öztürk, E., \& Hatirli, S. A. (2011). Analysis of Profit Inefficiencies in Turkish Hazelnut Agriculture. Tarım Bilimleri Dergisi, 17, 230-240.

Battese, G. E., \& Coelli, T. J. (1995). A Model for Technical Inefficiency Effect in Stochastic Frontier Production for Panel Data. Empirical Economics, 20, 325-345. https://doi.org/10.1007/BF01205442

Battese, G. E., \& Corra, G. S. (1977). Estimation of a Production Function Model with Applied to the Pastoral Zone of Eastern Australia. Australian Journal of Agricultural Economics, 21, 169-179. https://doi.org/ 10.1111/j.1467-8489.1977.tb00204.x

Bezlepkina, I. V. (2002). What is Behind the Fall in Russian Agricultural Production? The $\mathrm{X}^{\text {th }}$ EAAE Congress 
Exploring Diversity in the European Agri - Food System, Zaragoza (Spain), August 28-31, 2002. Retrieved from http://ageconsearch.umn.edu/bitstream/24785/1/cp02be90.pdf

Bird, R. M. (1974). Taxing Agricultural Land in Developing Countries. Cambridge, MA: Harvard University Press.

Casamatta, G., Rausser, G., \& Simon, L. K. (2011). Optimal taxation with joint production of agriculture and rural amenities. Resource and Energy Economics, 33, 544-553. http://dx.doi.org/10.1016/j.reseneeco.2010. 12.001

Chambers, R. G., Chung, Y., \& Färe, R. (1998). Profit, Directional Distance Functions, and Nerlovian Efficiency. Journal of Optimization Theory and Applications, 98-351. https://doi.org/10.1023/A:1022637501082

Godinho, M. L., \& Coelho, M. L. M. S. (2005). Typology of the Portuguese Farm Holdings and Taxation regimes. 94 ${ }^{\text {th }}$ EAAE Seminar 'From Households to Firms with Independent Legal Status: The Spectrum of Institutional Units in the Development of European Agriculture', Ashford (UK), April 9-10, 2005. Retrieved from http://ageconsearch.umn.edu/bitstream/24433/1/sp05go01.pdf

Hayran, S. (2013). Türkiye'de Tarım Kesiminin Vergilendirilmesi - Taxation of Agriculture in Turkey. Iğdır Üniversitesi Fen Bilimleri Enstitüsü Dergisi, 3(1), 69-72.

Hill, B., \& Blandford, D. (2007). Taxation Concessions as Instruments of Agricultural Policy. The Agricultural Economics Society's $81^{\text {st }}$ Annual Conference, University of Reading, UK, April 2-4, 2007. Retrieved from http://ageconsearch.umn.edu/bitstream/7976/1/cp07hi01.pdf

Huang, J., Liu, Y., Martin, W., \& Rozelle, S. (2008). Agricultural Trade Reform and Rural Prosperity: Lessons from China. NBER Working Paper No. 13958. National Bureau of Economic Research. https://doi.org/ $10.3386 /$ w 13958

Karim, M., \& Ebrahimi, A. E. (2013). Taxation of Agricultural Sector in Morocco: An Analysis Using a Dynamic General Equilibrium. EcoMod2013; International Conference on Economic Modelling, Prague, Czech Republic July 1-3, 2013. Retrieved from https://mpra.ub.uni-muenchen.de/45622

Khan, H. M. (2001). Agricultural Taxation in Developing Countries: A Survey of Issues and Policy. Agricultural Economics, 24, 315-328. https://doi.org/10.1016/S0169-5150(00)00075-X

Kolawole, O. (2006). Determinants of Profit Efficiency among Small Scale Rice Farmers in Nigeria: A Profit Function Approach. Poster paper prepared for presentation at the International Association of Agricultural Economists Conference, Gold Coast, Australia, August 12-18, 2006. Retrieved from http://ageconsearch.umn.edu/bitstream/25238/1/pp060688.pdf

Lin, J. Y., \& Lui, M. (2007). Rural Informal Taxation in China: Historical Evolution and an Analytic Framework. China \& World Economy, 15(3), 1-18. https://doi.org/10.1111/j.1749-124X.2007.00065.X

McMillan, M. S., \& Masters, W. A. (1999). A Political Economy Model of Agricultural Taxation, R\&D and Growth in Africa. Discussion Papers Series, Department of Economics, Tufts University 9903. Department of Economics, Tufts University. Retrieved from http://ase.tufts.edu/econ/papers/9903.pdf

Nelson, A. W. (1997). Rural taxation in Ethiopia, 1981-1989: A policy analysis matrix assessment for net producers and net consumers. Food Policy, 22(5), 419-431. http://dx.doi.org/10.1016/S0306-9192 (97)00032-8

Neumark, F., (1948). Genel Ekonomi Teorisi - General Theory of Economics. İstanbul, TR: İsmail Akgün Matbaası, İstanbul.

Rajaraman, I. (2004). Taxing Agriculture in a Developing Country: A Possible Approach. https://oi.org/10.1016/ s0573-8555(04)68812-2

Sidhu, S., \& Baanante, C. (1981). Estimating Farm-Level Input Demand and Wheat Supply in the Indian Punjab Using a Translog Profit Function. American Journal of Agricultural Economics, 63, $237-246$. https://doi.org/10.2307/1239559

Tantari, A., Severini, S., \& Rocchi, B. (2014). The taxation of farm income in Italy. $3^{\text {rd }}$ AIEAA Conference Feeding the Planet and Greening Agriculture: Challenges and Opportunities for the Bio-Economy. Alghero, June 25-27, 2014. Retrieved from http://www.aieaa.org/node/3

Tufan, A. (1988). Türkiye'deki Tarımsal Vergiler Üzerine Bir inceleme: An Analysis regarding Agricultural Taxation in Turkey (p. 68). Ankara, TR: Ankara Üniversitesi Ziraat Fakültesi Yayınları No: 1087. 
Yamane, T. (2001). In A. Esin, M. Akif Bakır, \& C. A. ve E. Gürbüzsel (Trans.), Temel Örnekleme Yöntemleri Main Methods of Sampling (Birinci Baskı, 1st issue). İstanbul, TR: Literatür Yayıncılık.

Zhong, C., Turvey, C., Zhang, J., \& Xu, C. (2011). Does taxation have real effects on agricultural output? Theory and empirical evidence from China. Journal of Economic Policy Reform, 14(3), 227-242. http://dx.doi.org/10.1080/17487870.2011.575105

\section{Notes}

Note 1. The financial data reported in Turkish Lira is converted into US Dollar using the average free market exchange rate of 06.2016 which is $1 \mathrm{USD}=2,9192$.

\section{Copyrights}

Copyright for this article is retained by the author(s), with first publication rights granted to the journal.

This is an open-access article distributed under the terms and conditions of the Creative Commons Attribution license (http://creativecommons.org/licenses/by/4.0/). 